\title{
VITAMIN A AND TOTAL PROTEIN LEVELS IN THE BLOOD PLASMA OF PIGLETS DURING THEIR POSTNATAL DEVELOPMENT
}

\author{
M. DVOŘAK
}

Veterinary Research Institute, 62132 Brno

Received September 3, 1985

A b s t r a c t

D v o ŕ á K M . : Vitamin A and Total Protein Levels in the Blood Plasma of Piglets During Their Postnatal Development. Acta vet. Brno, 55, 1986: 263-271.

A total of 559 fluorometric determinations of blood plasma vitaminA concentration were carried out in pigs from birth to 55 days of age. Its changes were studied in relation to body mass. and plasma total protein level. Newborn piglets of body mass less than $1 \mathrm{~kg}$ had a significantly lower level of vitamin $A$ and a non-significantly higher protein level than piglets of heavier birth body mass. After ingestion of colostrum the two parameters rose abruptly to several times their initial values. Vitamin A then retained its upward trend, with only occasional temporary cessation, up to the 4 th week after weaning, whereas the total protein level began to decline in the 2 nd week after birth. No significant differences were found between the heavy and light body mass piglets after ingestion of colostrum. Analysis of the changes in vitaminaemia during the first 14 days after weaning, which was carried out 4 weeks after birth, showed a direct relation of the increasing vitamin A concentration to the gains in body mass and therefore also to feed intake. It is inferred that supplementation of the commercial starter with 8000 IU vitamin A per kg was satisfactory. The results are evaluated with regard to transplacental and colostral transfer of vitamin A. Apparently, no relation exists between the retinol-binding protein and total protein levels in piglets.

Retinol, protein, body growth, nutrition, pig.

Vitamin A requirements of sows and piglets as well as the role of vitamin $A$ in the intra-uterine and postnatal development of the pig have been known in essence for a number of years ( $T$ ho mas et al. 1947; B r a ude et al. 1951; Frape et al. 1959; Palludan 1966). Fortification of feed mixtures with vitamin A has removed the incidence of clinical forms characteristic of its deficiency. However, various types of exertion to which animals are subjected, particularly under intensive husbandry practices, may increase their vitamin A requirements so that A-hypovitaminosis and its diagnosis in pigs continue to pose a challenge to the 
researcher. The problem is accentuated by possible shortcomings of feed mixtures particularly in the control of reproductive processes and in pig rearing ( $R$ a $s$ z $k$ et al. 1978). Whereas vitamin A changes in the blood plasma or serum of calves during late intra-uterine and postnatal life have been described also in this country ( $D$ vo ák 1959; S u r y nek et al..1976; J a go s et al. 1979) only few and incomplete data are available on these changes in piglets ( $\mathrm{S}$ i b b a ld et al. 1956; P o h l a n n and $S$ ander 1978). A recent finding is the detection of interactions of vitamin A with other nutrients, mainly protein. Of importance is not only. the quantity of protein ingested ( $R$ a o et al.. 1974; Underwood et al. 1979), but also the fact that retinol is

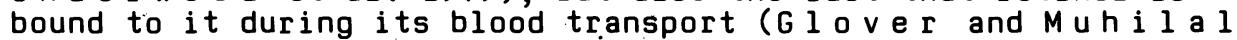
1976; $S \mathrm{~m} \mathrm{i} \mathrm{t}$ and $G$ o o d $\mathrm{m}$ a $\mathrm{n}$ 1979). Only vitamin A absorbed from the intestinal tract appears in the blood in the form of retinyl esters until it has been almost completely cleared from the circulation by the liver. In pigs the specific retinol-binding protein has the character of alpha,globulin and, compared with human retinol-binding protein, has a higher molecular weight and has shown no evidence of affinity to prealbumin

( $\mathrm{H}$ u a ng et al. 1972).

The retinol-protein complex plays an important role in the development of foetuses and newborn animals, for it affects both transplacental transport of vitamin A ( $T$ aka has hi et al. 1977) and its transfer from blood to milk ( $V$ ahlquist and $N i l s s o n$ 1979). Last but not least, the level of specific transport protein in the blood of foetuses and newborn animals may play a deciding role in the amount of circulating vitamin $A$ and, consequently, in securing the needs of the peripheral organs. No data regarding this postnatal situation in pigs are available. It has been established, however, that piglets are born with a very low concentration of total serum protein and have less alpha globulin at birth than during later life ( $\mathrm{T} u \mathrm{mble}$ s on and $\mathrm{Kal}$ i s h 1972). The present study was designed to investigate the changes in vitamin A concentration in the blood plasma of piglets from birth to the 4 th week after weaning in relation to toal plasma protein concentration and body mass.

\section{Materials and Methods}

Large White piglets from 27 litters raised in bedded pens in the Institute were employed. The sows were fed complete feed mixtures. The piglets were left on the sows till weaning at 4 weeks of age. They had access to Čos 1 , a commercial prestarter. After weaning they were placed on ČOS 2 , a commercial starter with 8000 IU vitamin A per $\mathrm{kg}$. No signs of clinical disease were observed. Blood collections from the cranial vena cava and weighing of the animals were carried out, with the exception of newborn piglets, between 7 and $9 \mathrm{a} . \mathrm{m}$. without previous food deprivation.

In the first part of our study 189 determinations of blood plasma vitamin $A$ and total protein concentration were performed in newborn and suckling piglets and 100 determinations were made in weaned piglets up to 55 days of age. The animals were divided 
into 9 age groups shown in Fig. 1. Zero day piglets were newborn animals before ingestion of colostrum. Each age category comprised 21 to 35 piglets which were divided according to body mass, thus forming subgroups of light and heavy body mass animals of 9 to 13 and 12 to 25 piglets, respectively. With the exception of newborn animals, each piglet was examined at least twice at two different ages.

It the second part of the study 270 determinations of blood plasma vitamin A and total protein were made in 90 piglets at weaning and 7 and 14 days after weaning. The object was to analyse the relation of plasma vitamin A concentration to body mass at weaning and to gains in body mass during the post-weaning period under study as well as the relation of increased vitamin $A$ and decreased total protein level to growth rate. Blood plasma vitamin A concentration was determined fluorometrically according to Thompson et al. (1973) using modifications described previously ( $D \vee 0$ rák et al. 1978). Total protein concentration was determined using Bio-La-Test kits (Lachema, Brno). The results are tabulated as arithmetic means + standard deviations and shown graphically as means \pm standard er⿳亠丷厂s. The significance of the differences of the meāns was assessed by student's t-test.

\section{Results}

Newborn piglets before ingestion of colostrum had a very low blood plasma vitamin A concentration, which was significantly $(P<0.05)$ higher in the subgroup of heavy body mass piglets $(0.26 \pm 0.09 \mu \mathrm{mol} / 1,1.25 \pm 0.16 \mathrm{~kg})$ than in light body mass animals $(0.14 \mp 0.08 \mu \mathrm{mol} / 1,0.69 \pm 0.08 \mathrm{~kg})$. On the other hand, there was no significant difference between the two subgroups in total protein concentration $(21.7+1.5$ vs. $25.4+7.6 \mathrm{~g} / 1)$. After ingestion of colostrum the blood pIasma vitamin $A$ concentration increased rapidly up to 17 days of age, at which time it reached a distinct peak in the light body mass piglets $(1.11+0.21 \mu m o l / 1)$. During the next month it fluctuated with no significant difference between the subgroups, retaining its upward trend particularly in heavy body mass animals, and did not reach its peak until the 4 th week after weaning ( Fig. l). Total protein concentration was very low in newborn piglets, rose abruptly after ingestion of colostrum and peaked on the 6 th days after birth, reaching $61.8 \pm 6.7$ and $60.2 \pm 6.3 \mathrm{~g} / \mathrm{l}$ in heavy and light body mass piglets, respectively. Then it declined up to 7 weeks of age and rose very slightly. at the end of the observation period (Fig. l). Except in the 2nd week after weaning, total protein level was invariably higher in heavy than in light body mass piglets, although the differences between the subgroups were not significant.

In the blood plasma of the dams examined after weaning vitamin A concentration was $0.92 \pm 0.22 \mathrm{umol} / 1$ and total protein level was $75.9+12.7 \mathrm{~g} / 1$.

Although no marked changes in vitamin A level after weaning are perceptible from the mean values presented in Fig. 1 , considerable differences were found in this respect between individual litters and animals. A similar situation was found on repeated examination of 90 piglets at weaning and 7 and 14 days after 

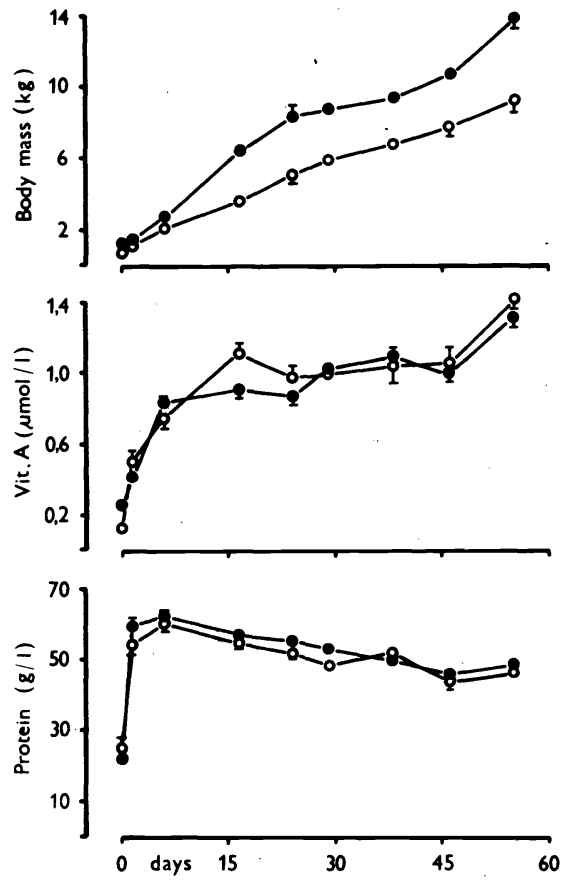

ig. 1. Budy illass, vitamin A and total protein levels in the blood plasma of light (open circles) and heavy (closed circles) body mass piglets suckled up to 4 weeks of age
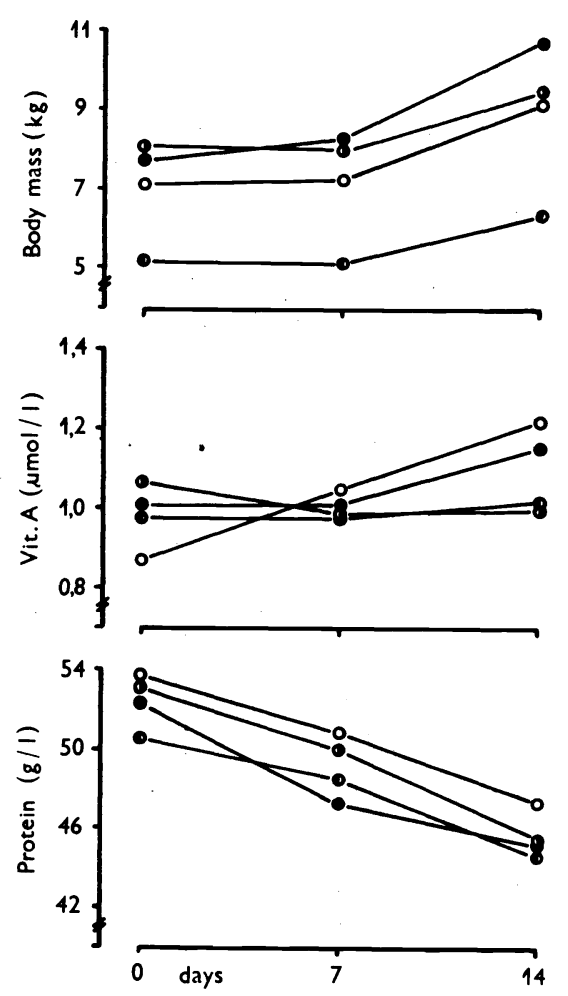

rig. 2. Relation of growth rate (expressed in terms of body mass) to vitamin $A$ and total protein levels in the blood plasma of four groups of piglets during the first 14 days after weaning (for explanatory notes see Results)

weaning: during this period there was a significant $(P<0.01)$ decrease in total protein, but little change in vitamin $A$ level $(1.02+0.22,0.99 \pm 0.20$ and $1.03 \pm 0.23 \mu \mathrm{mol} / \mathrm{l})$ and the gain in body masss was $1.46 \mathrm{~kg}$.

The relations of vitamin $A$ and total protein level to body mass were studied on 35 heavy body mass piglets $(8.05+1.02 \mathrm{~kg})$ and their 26 ligher littermates $(5.20+1.16 \mathrm{~kg})$ selected for this purpose from the original sample. The vitamin A concentration of the heavier piglets was at first slightly higher than in their lighter littermates $(1.07+0.21$ vs. $0.98 \pm 0.22 \mathrm{\mu mol} / 1)$, but decreased by the 7 th day so tha $\bar{t}$ the difference between the two groups disappeared (Fig. 2, semi-closed circles). The mean gains in body mass were relatively low: 1.40 and $1.15 \mathrm{~kg}$ in the heavy and light body mass animals, respectively. However, in 28 selected piglets with individual body mass gain of more than $2 \mathrm{~kg}$ (mean 
$2.89 \mathrm{~kg}$ ) a steady rise in vitamin A level was observed (Fig. 2, closed circles). Similarly, 32 piglets selected from the sample on the basis of a rise in vitamin A concentration by more than $0.14 \mathrm{\mu mol} / 1$ gained, on average, $1.98 \mathrm{~kg}$ (Fig. 2, open circles). This implies that good growth and health of the piglets, together with high feed intake and utilization, had a favourable effect on the circulating vitamin A level. Total protein concentration was not involved: during the 14-day period after weaning it decreased in all groups of piglets under study, least in those with the poorest gains in body mass ( $F i g .2$, semi-closed circles with the left half solid).

\section{Discussion}

Circulating vitamin A level of the young depends on the maternal organism, the main role being played by transplacental transfer and ingestion of colostrum. The availability of vitamin A to foetuses depends, among other things, on the type of placenta and may vary from species to species. The best situation in this respect is in man (Moor e 1957). A well-established fact is the limited possibility of transplacental transfer in cattle (Dan $n$ 1933). In bovine foetuses aged 8 to 9 months vitamin $A$ concentration in the blood plasma and liver was lower more than twice and ten times, respectively, than in the cows ( $\mathrm{J}$ a $\mathrm{g}$ o s et al. 1979). The observations in pigs, summarized in an earlier study ( $D \vee$ o ŕa $k$ 1967), suggest that the supply of vitamin A to newborn piglets is relatively low, but its content in the whole liver can be more than hundredfold increased by massive vitamin $A$ supplementation of pregnant sows as compared with animals on a vitamin A-deficient diet. Piglets farrowed by sows receiving various levels of dietary vitamin A showed corresponding differences in vitamin A content of the liver, but not of the blood plasma ( $P$ oh $l$ a $n$ and $S$ ande.r 1978).

Very low A-vitaminaemia in piglets before ingestion of colostrum suggests a relatively low need for vitamin A transfer to body tissues during late intra-uterine development and, presumably, a low level of the specific protein that binds retinol during its transport in blood. This view is substantiated by the finding that total protein concentration was low at birth and increased rapidly after ingestion of colostrum, reaching a peak as early as the 6 th day in piglets left on the sows. In line with these observations is the finding of increasing plasma vitamin $A$ whose rise, however, was not abrupt but almost continuous. Only in piglets of the lower growth rate, expressed in terms of body mass gain, this rise ceased temporarily for about one month after the 17 th day. It can be concluded that a corresponding $r$ ise occurred in the level of the specific protein, to which retinol is bound. It appears likely that alpha,-globulin is mainly of colostral origin, later it can be synthesized in the body of the piglet. Qualitative changes in plasma protein during piglet development are not yet fully understood, but some published data ( Tumbleson and Kalish 1972; Hakkara inen 1975) support the aforementioned hypothesis. However, consideration should also be given to the possibility that part of the vitamin $A$ 
determined is made up of unbound retinyl esters after absorption from the intestinal tract, particularly under conditions of high vitamin A intake during colostral feeding.

Both the quality and quantity of colostrum ingested by individual piglets apparently.play a deciding role in the increase of vitamin A concentration in the liver. ( $D \vee 0$ a $k$ 1967) and blood plasma in the first days after birth. Vitamin A content of colostral fat is about four times that of milk in the first week and about five times that found in milk in the fourth week of lactation ( $B \circ \mathrm{wl}$ and et al. 1951). However, colostrum is not ingested equally by all piglets; considerable individual variation in colostrum intake was reported ( $A \mathrm{um}$ a $\mathrm{t} r \mathrm{e}$ and $\mathrm{S} e \mathrm{v}$ e 1978). Therefore even littermates may difer in their plasma vitamin $A$ levels. Thus vitamin A reserves obtained during intra-uterine life presumably play only a minor role in later life of the piglets. In light birth body mass pigs unsatisfactory vitamin A supply during foetal life may occur as a result of non-uniform distribution of the maternal and foetal blood flow in the placenta which fat-soluble vitamins pass by way of passive diffusion ( $\mathrm{H}$ i $1 \mathrm{l}$ and $\mathrm{L}$ o $\mathrm{ng}$ o 1980).

The results suggest that from the 2 nd postnatal week onwards vitamin A concentration in the blood plasma of pigs is no longer related to total plasma protein concentration, which decreases in consequence of the decreasing globulin fraction ( $T$ u m b l e s o $n$ and $K$ a $l$ is $h$ 1972), and does not provide information at this time about the metabolism of protein ( $D \vee 0$ ák 1978). The level of the specific vitamin A-binding protein, though depending also on protein nutrition, is in the first place specifically regulated by the nutritional vitamin A status; administration of retinol to vitamin A-deficient subjects stimulates rapid secretion of this protein from the liver into the blood ( $G$ l o ver and $\mathrm{Muh}$ i l a l. 1976; $\mathrm{Sm} \mathrm{ith}$ and $\mathrm{G}$ o o d m a n 1979).

In an earlier study ( $S$ i b b a 1 d et al. 1956) blood plasma vitamin A level of suckling piglets was found to be related to that of their dams, being generally lower in the former. In the present study it was, with the exception of the first postnatal week, approximately at the same level as in the dams. In large herds blood plasma vitamin A concentration was highest in sows on the 23 rd day after farrowing ( $1.26 \pm 0.23 \mu \mathrm{mol} / 1)$ and decreased slightly afterwards ( $R$ a s y y et al. 1978). There can be little doubt that changes in A-vitaminaemia in piglets may vary according to the vitamin value of complete feed mixtures. Further increase in vitaminaemia, which was most marked in piglets with the greatest gains in body mass and in the $3 \mathrm{rd}$ post-weaning week after adaptation to the feed and with its increasing consumption, indicates satisfactory supplementation of the starter with vitamin $A$. In this respect piglets are not affected adversely by the withdrawal of nursing in contrast to their situation as to the provision of vitamin E. Blood plasma vitamin E levels of suckling piglets are similar to those of vitamin $A$ only to about 10 days of age and then decline, being particularly low after weaning D vo ŕák 1974).

\section{Hladiny vitamínu A a celkové bilkoviny $v$ krevní plazmě během postnatálního vývoje selat}

Bylo provedeno 559 fluorometrických stanovení koncentrace vitamínu A v krevní plazmě selat od narození do stárí 55 dní. Její zmè- 
ny byly sledovány ve vztahu $k$ tělesné hmotnosti a $k$ hladině celkového proteinu $v$ plazmě. Novorozená selata s hmotností menší než 1 kg měla prủkazně nižši hladinu vitamínu A a neprủkazně vyšší hladinu proteinu než selata těžsí. Shodnè jevila płi kolostrální výživě u obou parametrủ rychlé několikanásobné zvýšení, jehož trend zưstal u vitamínu A zachován s pł́padným přerušením až do 4. týdne po odstavu, kdežto hladina celkového proteinu se již $v 2$. týdnu života začala snižovat. Mezi selaty s větší nebo menši tělesnou hmotností nebyly po př́imu mleziva zjištěny prủkazné rozdily. Analýza variability změn vitaminémie během 14 dnư po odstavu selat od prasnice, prováděném 4 týdny po narození, ukázala př́mý vztah zvyšjúcí se koncentrace vitamínu A s pŕirủstky tělesné hmotnosti a tím i s pŕjjmem krmiva. Bylo usouzeno na vyhovujici suplementaci obchodniho starteru s $8000 \mathrm{~m} . j$. vitamínu $A v$ kilogramu. Výsledky jsọu hodnoceny $z$ hlediska transplacentárníno a kolostrálníno přenosu vitamínu A. Je diskutováno o významu specifického proteinu, který váže v krevní plazmě retinol. Se změnami hladiny celkového proteinu u selat není zřejmě $\checkmark$ korelaci.

$\frac{\text { Уровни. витамина А и овщего белка в хровяной }}{\text { плазме в ходе послеродового развития свинох }}$

Проводили 559 флюориметрических определений концентрации витамина А в хровяной плазме свинох со дня рождения до возраста 55 сутох. Их изменения исследовали по отношению $\mathbf{x}$ массе тела и уровню общего протеина в плазме. Новопожденные свинхи массо менее 1 кг отличались значительно более низхим уровнем витамина А и несущественно более высохим уровнем протеина по сравнению с более тяжелыми свинками. При молозивном питании у обоих параметров аналогично проявилоць быстрое, многохратное увеличение, тенденция которого оставалась у витамина А без изменений с возможным прехращением до 4 недели после отъема, но уровень общего протеина уже на 2 неделе жизни начинал понижаться. Между свинхами с большей или меньшей массой тела не было после питания молозивом установлено существенной разницы. Анализ вариабельности изменений витаминемии в течение двух недель после отъема свинох от свиноматки, проводимый 4 недели после опороса, выявил прямое отношение повышающейся хонцентрации витамина А С приростом веса тела и, тем самым, с расходом хормов. Предполагается удовлетворительная замена торгового стартера с 8000 м ед. витамина А в 1 килограмме. Проводилась оценка результатов с точки зрения трансплацентарной и молозивной передачи витамина А. Обсуждается значение специфического протеина, связывающего ретинол в хровяной плазме. Он, видим, не находится в хорреляции с изменениями уровня обшего протеина у свинох.

\section{References}

AUMAITRE, A. - SEVE, B.: Nutritional importance of colostrum in the piglet. Annls Rech. vét., 9, 1978: 181- 192 .

BOWLAND, J. P. - GRUMMER, R. H. = PHILLIPS, P. H. - BOHSTEDT, G.: Seasonal variation in the fat, vitamin $A$, and vitamin $D$ content of sow's colostrum and milk. J. Animal Sci., 10, 1951': 
BRAUDE, R. - KON, S. K. - MITCHELL, K. G. - THOMPSON, S. N.: Some observations on vitamin A requirements of pigs. Vet. Rec., 63, 1951: $671-673$.

DANN, W. J.: The transmission of vitamin A from parents to young in mammals. II. The carotene and vitamin A content of cow's colostrum. Biochem. J., 27, 1933: 1998.

DVOR̆ÁK, M.: Vitamin A a karoten v krevní plasmě sajících telat a jejich závislost na mateřském organismu. Sborník VSZL, Spisy Fak. vet., 7, 1959: $399-417$.

DVOŔÁK, M.:'Záávislost obsahu vitaminu A v játrech selat na jeho pŕivodu prasnicím během březosti. Docum. vet., Brno, 6, 1967: $21-28$.

DVOŔAK, M.: Levels of vitamin $E$ in the blood plasma of suckling and weaned piglets. Acta vet. Brno, 43, 1974: $103-110$.

DVOŔAK, M.: Main nutrient plasma metabolite levels in piglets from birth through six weeks of age and in feeder pigs. Acta vet. Brno, 47, 1978: 115-122.

DVOŘÁK, M. - HERZIG, I. - VOJTISEK, B. - TOULOVÁ, M.: Hladiny karotenu a fluorometricky stanoveného vitamínu $A v$ krevní plazmě krav ve vztahu $k$ březosti a typu krmení. Vet. Med., Praha, 23, 1978: 577 - 585 .

FRAPE, D. L. - SPEER, V. C. - HAYS, V. W. - CATRON, D. V.: The vitamin A requirement of the young pig. J. Nutr., 68, 19.59: 173 - 187 .

GLOVER, J. - MUHILAL, H.: Nutritional factors affecting the biosynthesis of retinol-binding protein in the liver and its release into plasma. Int. J. Vitam. Nutr. Res., 46, 1976: 239 - 243 .

HAKKARAINEN, J.: Developmental changes of protein, RNA, DNA, Iipid, and glycogen in the lier, skeletal muscle, and brain of the piglet. Acta vet. scand., Suppl. 59, 1975: $198 \mathrm{p}$.

HILL, E.P. - LONGO, L. D.: Dynamics of maternal-fetal nutrient transfer. Fedn Proc., 39, 1980: 239 - 244.

HUANG, C. C. - HOWARTH, R. E. - OWEN, B. D.: Porcine retinol binding protein. Comp. Biochem. Physiol., 42 B, 1972: 57 - 64 .

JAGOS, P. - BOUDA, J. - GERYK, J.: The plasma levels of vitamins $A, E$ and carotene in cows in late pregnancy and in their foetuses. Acta vet. Brno, 48, 1979: $19-23$.

MOORE, T.: Vitamin A. Amsterdam, London, New York, Princeton, $1957,645 \mathrm{p}$.

PALLUDÁN, B.: A-avitaminosis in swine. Copenhagen 1966, 273 p.

POHLANN, R. - SANDER, W.: Vitamin A-Gehalt in Organen von Sauen und Ferkeln bei unterschiedlicher Vitamin A-Versorgungslage. Tierhygiene-Information, Sonderheft RGW- Symposium Stoffwechselkontrolle und -prophylaxe bei Rindern und Schweinen in industriemässigen Anlagen, 1978: 163 - 168.

RAO, M. S. S. - THYAGARAJAN, K. - KISHORE, G. S. - CAMA, H. R.: Vitamin A metabolism under nutritional stress. Int. J. Vitam. Nutr. Res., 44, 1974: 151 - 158.

RASZYK, J. - DVORAK, M. - ČANDERLE, J.: Physiologische Veränderungen der Vitamin A-Konzentration im Blutserum von Mutterschweinen im Laufe des Reproduktionszyklus. Tierhygiene-Information, Sonderheft RGW-Symposium Stoffwechselkontrolle und -prophylaxe bei Rindern und Schweinen in industriemässigen Anlagen, 1978: 159 - 162 . 
SIBBALD, I. R. - BOWLAND, J. P. - BERG, R. T.: The relationship between the blood plasma vitamin A levels of sows and of their suckling pigs. J. Anim. Sci., 15, 1956: 400-406.

SMITH, J. E. - GOODMAN, D. S: : Retinol-binding protein and the regulation of vitamin A transport. Fedn Proc., 38, 1979: $2504-2509$.

SURYNEK, J. - SLAMOVÁ-SKOLLOVA, Z - JURKA, F.: Hladina B-karoténu a vitamínu $A v$ krevní plazmě telat $v$ prvních čtyřech měsících postnatálního údobí. Vet. Med., Praha, 21, 1976: $669-674$.

TAKAHASHI; $Y$. I. - SMITH, J. E. - GOODMAN, D. S.: Vitamin A and retinol-binding protein metabolism during fetal development in the rat. Am. J. Physiol., 233, 1977: E263 - E272.

THOMAS, J.W. - LOOSLI, J.K. WILLIAM, J. P.: Placental and mammary transfer of vitamin $A$ in swine and goats as affected by the prepartum diet. J. Animal Sci., 6, 1947: 141-145.

THOMPSON, J. N. - ERDODY, P. - MAXWELL, W. B.: Simultaneous fluorometric determinations of vitamins $A$ and $E$ in human serum and plasma. Biochem. Med., 8 , 1973: 403 - 414 .

TUMBLESON, M. E. - KALISH, P. R.: Serum biochemical and hematological parameters in crossbred swine from birth through eight weeks of age. Can. J. comp. Med., 36, 1972: $202-209$.

UNDERWOOD, B. A. - LOERCH, J. D. - LEWIS, K. C.: Effects of dietary vitamin A deficiency, retinoic acid and protein quantity and quality on serially obtained plasma and liver levels of vitamin $A$ in rats. J. Nutr., 109, 1979; 796 - 806.

VAHLQUIST, A. - NILSSON, S.: Mechanisms for vitamin A transfer from blood to milk in rhesus monkeys. J. Nutr., 109, 1979: $1456-1463$. 